\title{
Lutzomyia longipalpis BEHAVIOR AND CONTROL AT AN URBAN VISCERAL LEISHMANIASIS FOCUS IN ARGENTINA
}

\author{
Maria Soledad SANTINI(1,4), Oscar Daniel SALOMÓN(1,4), Soraya Alejandra ACARDI(2,4), Enrique Adolfo SANDOVAL(3) \& Lilian TARTAGLINO(3)
}

\begin{abstract}
SUMMARY
During the earlier stages of visceral leishmaniasis transmission in Posadas City, Misiones, both the night activity and attraction to humans of Lutzomyia longipalpis were assessed, in order to provide preliminary recommendations. The impact of peridomestic deltamethrin spraying performed by local officials was also evaluated. Although Lu. longipalpis were found in traps located over a dog the entire night, $90 \%$ of the females were captured from $20.30 \mathrm{~h}$ to $1.30 \mathrm{~h}$, and only landed on a human when he was at a distance of $1.5 \mathrm{~m}$ from the dog. Peridomestic spraying of deltamethrin $\left(25 \mathrm{mg} / \mathrm{m}^{2}\right)$ reduced the sand fly capture up to seven days post-intervention without dispersion in the border of the sprayed areas. These results support the recommendations about time-space focus of the protection measures: first half of the night, in the backyard, with pets and domestic animals kept at least $5 \mathrm{~m}$ from humans. The deltamethrin as it was used did not seem very effective in this scenario; neither did the eventual use of bed nets, at least in adults, due to the place/hour of sand fly higher activity. This study strengthens the need for a multidisciplinary approach to develop prevention strategies based both on biological and anthropological studies.
\end{abstract}

KEYWORDS: Lutzomyia longipalpis; Visceral leishmaniasis; Deltamethrin.

\section{INTRODUCTION}

Visceral leishmaniasis (VL) is the most severe form of leishmaniasis. In Latin America VL is caused by the parasite Leishmania (L.) infantum (syn. chagasi), with the domestic dog (Canis familiaris) as the main reservoir in urban environments, and the phlebotomine Lutzomyia longipalpis as the major vector in Central and South America ${ }^{16,19}$.

VL was previously known as a rural disease, but large outbreaks and new urban foci have recently been reported in the Americas ${ }^{11,16,17,19,24}$.

Argentina reported 14 autochthonous human cases with visceral involvement in the country from 1925 to 1989 , scattered in time and space. At this time Lu. longipalpis had been captured in Argentina twice, in two localities near the city of Posadas, Misiones province, where previously there were no records of VL cases ${ }^{33}$. More recently in 2005, Lu. longipalpis was found in Clorinda City on the border with Paraguay, with no VL human cases ${ }^{32}$.

In May 2006 the first human autochthonous case of VL associated with $L$. infantum infected dogs and $L u$. longipalpis was reported from the city of Posadas ${ }^{31}$. From May 2006 up to November 2009, 39 cases of human VL, five fatal, were reported from the Posadas city area (PosadasGarupá), while in the same area thousands of dogs were infected, and $L u$. longipalpis and canine VL were already dispersed $350 \mathrm{~km}$ south from Posadas, in Monte Caseros, Corrientes province ${ }^{30}$.

The objective of this study was to provide preliminary recommendations during the earlier stages of VL transmission in an emergent urban focus. The night activity of Lu. longipalpis and their attraction to humans where people actually stay during the risk hours were assessed, as was the impact of peridomestic insecticide spraying performed by local officials. These results could help in the design of further studies to develop a rational control strategy.

\section{MATERIALS AND METHODS}

The city of Posadas $\left(27^{\circ} 23^{\prime} \mathrm{S} ; 55^{\circ} 53^{\prime} \mathrm{W}, 120\right.$ masl), is the capital of Misiones province in the northeastern border of Argentina. The city was originally part of the Paranaense Forest, a subtropical humid forest from the Amazonian domain ${ }^{5}$, with a mean annual temperature of $22.2^{\circ} \mathrm{C}$ and a mean annual precipitation of $1699 \mathrm{~mm}$ (years 2003 to 2007, Instituto Nacional de Estadísticas y Censos, 2009). It is the most populated city of the province, with more than 250,000 inhabitants (Instituto Nacional de Estadísticas y Censos, 2001).

Phlebotominae sand flies were captured in the city of Posadas using CDC battery powered mini light traps overnight ${ }^{35}$. The traps were located

(1) Centro Nacional de Diagnóstico e Investigación en Endemo-epidemias, Administración Nacional de Laboratorios e Institutos de Salud, Ministerio de Salud de la Nación, Argentina.

(2) Laboratorio de Biología Molecular Aplicada, Facultad de Ciencias Exactas, Químicas y Naturales, Universidad Nacional de Misiones, Argentina.

(3) Laboratorio de Vectores, Secretaria de Calidad de Vida, Municipalidad de Posadas, Misiones, Argentina.

(4) Investigadores del CONICET (Consejo Nacional de Investigaciones Científicas y Técnicas). Argentina.

Correspondence to: Dra. Ma. Soledad Santini, Avenida Paseo Colón 568, (1063) CA Buenos Aires, Argentina. Fax: (54-11) 4331 2536. E-mail: mariasoledadsantini@ gmail.com 
SANTINI, M.S.; SALOMÓN, O.D.; ACARDI, S.A.; SANDOVAL, E.A. \& TARTAGLINO, L. - Lutzomyia longipalpis behavior and control at an urban visceral leishmaniasis focus in Argentina. Rev. Inst. Med. Trop. Sao Paulo, 52(4): 187-91, 2010.

in the 'worst scenario': the peridomestic environment most prone to have phlebotomine ${ }^{6,15}$. The trap was hung in a shadowy place, at $1.5 \mathrm{~m}$ from the ground, close to dogs or chickens as blood source. The dates and places are described below. All the sand flies captured were preserved dry and clarified in lactofenol 1\%, the species was identified according to the key of Young \& Duncan (1994), with the modification of ANDRADE FILHO et al. $(2003)^{4}$.

The study of Phlebotomine distribution by hour was performed in the backyard of the first reported case of human VL (S27 $23^{\prime}$ 00”, W55 $\left.54^{\prime} 19^{\prime \prime}\right)^{32}$. The CDC trap was located in a three-wall storeroom over a dog during five consecutive nights from $2 / 12 / 2007$ to $16 / 12 / 2007$. The bag of the trap was changed at each hour from $19.30 \mathrm{~h}$ to $7.30 \mathrm{~h}$, and the temperature and relative humidity were recorded with a digital device. The results were expressed as the relative abundance (\%) by hour for each night $(100 \%)$ and the mean of the five nights was computed.

In the same place during three nights the principal investigator exposed only a rectangle of the internal face of one of his thighs, and collected any sand flies that landed before they tried to bite and any sand flies that landed in the clothed area with a mouth aspirator. These captures were done during different nights when the principal investigator was $5 \mathrm{~m}, 3 \mathrm{~m}, 2.5 \mathrm{~m}$ from the dog in the direction of the odor plume, and during the last night a capture at " 0 " $\mathrm{m}$ from the dog was performed over a five minute period each hour during the hours of highest sand fly activity (21.30h-24.30h).

From the data provided by the regular monitoring of sand flies, (unpublished data) six houses with $\geq 60 \mathrm{Lu}$. longipalpis/trap/night separated from each other by at least $400 \mathrm{~m}$ were selected. After the informed consent was signed by the householder and his neighbors, three out of the six houses were sprayed with deltamethrin (EC $10 \% \mathrm{w} / \mathrm{v}$ ) diluted to $62.5 \mathrm{~mL} / 10 \mathrm{~L}$ in order to obtain a dosage of $25 \mathrm{mg} / \mathrm{m}^{2}$. The solution was applied with backpack sprayers with fan producer peaks at a flux of $900 \mathrm{~mL} / \mathrm{min}$ on the external walls of the domicile, peridomestic dwellings and tree trunks up to $200 \mathrm{~m}$ from the house. At the three sprayed houses, the three houses without spraying (control), and three houses non sprayed but located just in the border of the intervention area (control of dispersion due to the insecticide) CDC traps were located as described above during the day " 0 " (pre-intervention night) and on the $3^{\text {rd }}, 7^{\text {th }}$ and $14^{\text {th }}$ days post-intervention.

The hour-abundance analysis was made by linear multiple regression, with relative humidity and temperature as independent variables (adjusted by quadratic transformation). The interventions were compared with Tukey`s test with the values transformed to percentages (day " 0 "- $100 \%$ for each house).

\section{RESULTS}

The captures discriminated by hour collected 959 phlebotomine (181 female and 778 males), all Lu. longipalpis, during five consecutive nights (140, 228, 124, 427 and 40 sand flies/night). Significantly more sand flies were captured between $21.30 \mathrm{~h}$ to $0.30 \mathrm{~h}$ than $0.30 \mathrm{~h}$ to $7.20 \mathrm{~h}$ ( $\mathrm{p}=0.0001$ ). Furthermore, $90 \%$ of the females were captured from $20.30 \mathrm{~h}$ to $1.30 \mathrm{~h}$, but only $63 \%$ of the males (males-female abundance $\mathrm{p}=0.0348$ ) (Fig. 1).

The relative abundance of $\mathrm{Lu}$. longipalpis by the hour was associated with the mean temperature/hour $(p=0.0072)$ and relative humidity $(p$
$=0.0077$ ) with a $\mathrm{R}^{2}=0.60$. When only the females were taken into account, the relative abundance was again associated with temperature and humidity ( $\mathrm{p}=0.0164$ and $\mathrm{p}=0.0156$ respectively) but with $\mathrm{a} \mathrm{R}^{2}=$ 0.87 , while the males abundance besides with temperature $(\mathrm{p}=0.0517)$ and humidity $(\mathrm{p}=0.0259)$ showed association also with the female abundance ( $<$ < 0.0001) (Fig. 1). The "window" with higher abundance for females of $\mathrm{Lu}$. longipalpis was between $63 \%$ and $68 \%$ of relative humidity and between $26^{\circ} \mathrm{C}$ and $28^{\circ} \mathrm{C}$, the linear regression suggested that females are captured from $23^{\circ} \mathrm{C}$ up.

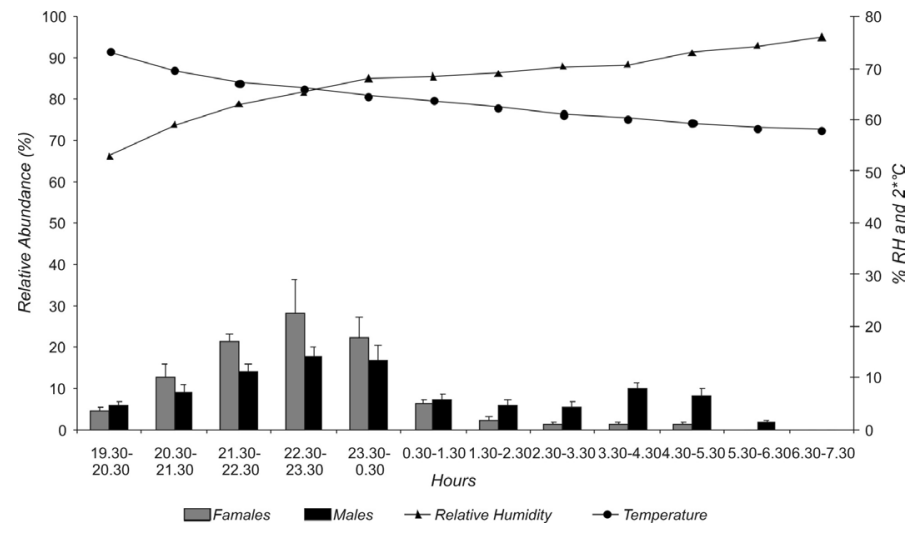

Fig. 1 - Distribution of Lu. longipalpis abundance by hour and gender. The relative abundance (\%) was computed for each night $(100 \%)$ and the mean of five nights were computed and depicted as bars (+ DE). The averages of the Relative Humidity $(\mathrm{RH})$ and Temperature $\left({ }^{\circ} \mathrm{C}\right)$ by hour for the five nights were shown as curves, Posadas, Argentina, 12/2/2007-12/16/2007.

Lu. longipalpis did not land on man at $5 \mathrm{~m}$ and $3 \mathrm{~m}$ from the dog, although the CDC trap collected 140 and 228 individuals respectively on the same nights. When the distance between the dog/trap and the human was $1.5 \mathrm{~m}, 38$ sand flies landed on the human $(30.6 \%$ of the CDC trap performance), and at " 0 " $\mathrm{m}$ up to 12 sand flies were observed for five minutes, almost half of those were observed on the dog.

During the intervention in the nine houses studied 7,306 Phlebotominae were collected all belonging to the species $\mathrm{Lu}$. longipalpis. The results showed a significant reduction of the sand fly captures up to seven days post-intervention $(\mathrm{p} \leq 0.05)$, and a trend of increasing abundance afterwards, but were not considered significantly different from the controls due to the high deviation of the data (Fig. 2). The houses just on the border of the intervention did not show differences in abundance from the controls but were significantly different from the sprayed houses up to the day 7 post-intervention (Fig. 2).

\section{DISCUSSION}

This study was performed in order to assess different aspects of risk during the earlier stages of VL human transmission in Posadas City, Argentina, the southernmost focus known up to now, in order to develop preliminary recommendations. The hourly activity of $\mathrm{Lu}$. longipalpis in peridomestic habitats during the summer suggested that the insects become active after sunset, but the females were significantly more abundant $(70 \%)$ from $21.30 \mathrm{~h}$ to $0.30 \mathrm{~h}$, and the male abundance was correlated with that of the females. In spite of the recruiting role for males suggested many times, it has also been suggested that at least for new infestations the females are the first attracted to host odors ${ }^{27}$. On the other 


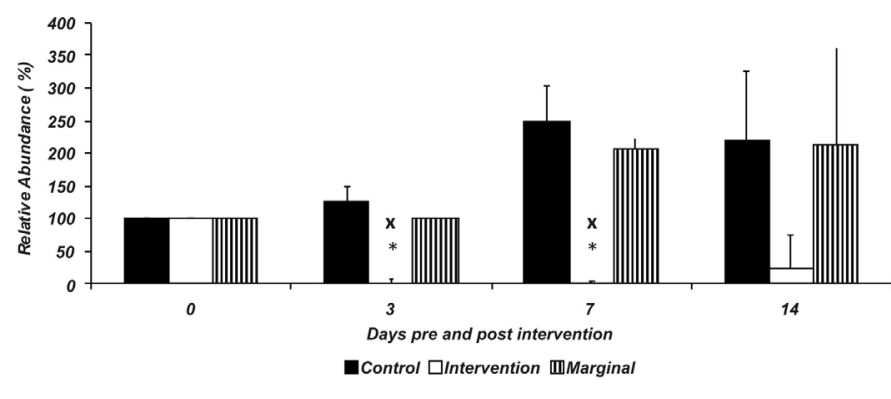

\begin{tabular}{|c|c|c|c|c|}
\cline { 2 - 5 } \multicolumn{1}{c|}{} & Day 0 & Day 3 & Day 7 & Day14 \\
\hline Control & $100(0.00)$ & $76.95(9.43)$ & $38.70(24.83)$ & $77.90(47.30)$ \\
\hline Intervention & $100(0.00)$ & $6.12(3.50)$ & $5.39(2.09)$ & $32.78(22.81)$ \\
\hline Marginal & $100(0.00)$ & $100(0.00)$ & $109.95(9.95)$ & $129.30(85.34)$ \\
\hline
\end{tabular}

Fig. 2 - Abundance (+ SD) of Lu. longipalpis in peridomicile CDC located traps in Deltamethrin sprayed houses (intervention), non sprayed houses more than $400 \mathrm{~m}$ away (control), and houses just out of the border of the intervention $200 \mathrm{~m}$ from intervened houses (marginal). The samples were taken at day 0 (pre-intervention night), and days 3, 7 and 14 post-intervention. Significant differences of sprayed houses from control $\mathbf{x}$, from marginal houses *. The table below the graphic shows sample averages (SD).

hand, these data does not discriminate the effects of the hour (biological clock) from the weather variables, as there was an optimal "window" for the female activity between $26^{\circ} \mathrm{C}-28{ }^{\circ} \mathrm{C}$ and with the humidity below $68 \%$. However, in Colombia, two patterns of nocturnal activity of $\mathrm{Lu}$. longipalpis were reported, one peaked early in the evening (18.30-23.30 hours) and then declined towards the morning, with an increased activity also above $24^{\circ} \mathrm{C}^{25}$. In Venezuela the greatest activity of this species was recorded before $23.00 \mathrm{~h}^{15}$, and in Maranhão, Brazil, in animal sheds $L u$. longipalpis was mainly collected between $18.00 \mathrm{~h}$ and $20.00 \mathrm{~h}^{29}$. These results highlight the risk associated with the nocturnal habits of the people of Posadas, who usually remain in their backyards during the summer months from dinnertime to around midnight. In this cultural frame the eventual impact of impregnated nets or curtains would be very low, as the people are neither in bed nor inside the house during the peak of vector activity. Otherwise repellents with effects in semi-open spaces could be more useful. However, the use of bed nets could not be discarded for small children that are sleeping inside the house or in the backyard besides their parents during dinner (almost $12 \%$ of the cases up to now).

Lu. longipalpis in this southern focus were strongly attracted to dogs, the main urban reservoir of $L$. infantum. The sand flies landed on a human only when the dog was at $1.5 \mathrm{~m}$ or closer. The dog preference was reported for some older foci ${ }^{37}$ or as a factor associated with higher abundance of Lu. longipalpis ${ }^{28}$, but in other studies was not a highly preferred blood source ${ }^{10,23,26,34}$. Besides geographical differences of behavior within $L u$. longipalpis complex subspecies, the blood relative preference of different species in those studies based on gut content could be associated with the spatial distribution of traps and hosts and the opportunistic behavior of the vector. The host attractiveness observed in Posadas could be then also associated with an increased risk during dinner in the backyard, when the dogs were usually around, and in close contact with the people. When the captures with human protected bait were performed in the adjacent house the children were playing, embracing dogs up to $22.00 \mathrm{~h}$, as it is usual in the city. Furthermore, unpublished results from the same focus showed that having chicken coops in the yard increased the odds ratio of presenting high abundance of $\mathrm{Lu}$. longipalpis three times.
Thus, these results support the recommendation to keep dogs and other domestic animals at least five meters from the sleeping place of humans, and to avoid the interaction with unprotected animals (by repellents) or environments (by insecticides) during the night.

However, with respect to insecticides, a new vector-borne disease usually leads to a city-wide spatial spraying of insecticide. The impact of the use of deltamethrin by county officials in the peridomestic environments of houses with high density of sand flies was assessed. The data obtained only allowed us to ascertain that the pyrethroid decreased Lu. longipalpis densities in the first seven days after intervention, but did not increase the dispersion of vector to the sprayed border areas. Although some studies reported deltamethrin residual effects up to 9-12 months inside houses ${ }^{13,19}$, strong anti-feeding effects when applied to dogs as collars or topically, and repellent effects in impregnated bednets ${ }^{7,89}$, and pyrethroids as lambdacyalothrin reducing impact on Lu. longipalpis sand fly captures after focal or indoor applications ${ }^{14,18}$, there are many reports about the short or transient effects of fenitrothion ${ }^{14}$, cypermethrin ${ }^{12}$ and deltamethrin as peridomestic sprayed insecticide ${ }^{1,13,22,36}$. Unfortunately the effects of insecticides for longer periods than 14 days could not be assessed in this study due to an abrupt change in the weather conditions that reduced the population; both in the intervention and the control group, but the results obtained were consistent with the literature. Therefore, the recommendation about focus interventions by insecticides need further validation in this southern focus, with risk focused outside the house during the first half of the night, with improved active principles, formulations, ways of applications, and strategies that take into account also the environmental and reservoir risk factors ${ }^{1,3,17}$. In this context, FELICIANGELI et al. ${ }^{14}$ after a controlled trial, proposed lambda-cyalothrin indoor spraying three times per year, with a dose higher than usual. However, even if the outdoor associated risk is not taken into account, this strategy could only be applied at microfocal level and not in city-wide programs, further when the indiscriminate use of insecticides could induce resistance both in target and not targeted species ${ }^{1}$, and pyrethroids have been used broadly in Aedes control.

In conclusion, this short term assessment of risk scenarios in a recent and previously unknown focus of VL generated preliminary recommendations: a) the individual protection (clothes, repellents, bednets) should be intensified during the first half of the night, mainly when the people remains outdoors; b) the dog and chicken sleeping areas should be as far as possible or at least five meters from the human sleeping area; c) the insecticide spraying effectivity should be assessed, while the use of delthamethrin as it is used is questioned, and the eventual use of impregnated fabric strategies could be focused only in small children. On the other hand, the observations about the risk associated with habits and behaviors during the peak of vector activity related to human exposure, human-dog interaction and chicken management, strengthened the need of anthropological approaches besides the biological studies, in order to develop recommendations based on the perception of risk among the population and how it could be changed.

\section{RESUMO}

\section{Comportamento e controle de Lutzomyia longipalpis em foco de leishmaniose visceral urbana na Argentina}

Durante os estádios precoces de transmissão da leishmaniose visceral na cidade de Posadas, Misiones, foi avaliada a atividade noturna da 
SANTINI, M.S.; SALOMÓN, O.D.; ACARDI, S.A.; SANDOVAL, E.A. \& TARTAGLINO, L. - Lutzomyia longipalpis behavior and control at an urban visceral leishmaniasis focus in Argentina. Rev. Inst. Med. Trop. Sao Paulo, 52(4): 187-91, 2010.

Lutzomyia longipalpis e a atração pelos seres humanos, para fornecer recomendações preliminares. $\mathrm{O}$ impacto do inseticida deltametrina peridoméstico, e a borrifação executada por funcionários locais, também foi avaliada. Embora existam Lu. longipalpis atingindo as armadilhas localizadas perto de um cão durante toda a noite, $90 \%$ das fêmeas foram capturadas a partir das $20.30 \mathrm{~h}$ até $1.30 \mathrm{~h}$, e só atinge seres humanos quando estão a 1,5 m do cão. A borrifação peridoméstica com deltametrina ( 25 $\mathrm{mg} / \mathrm{m}^{2}$ ) reduziu a área de captura da mosca da areia, até sete dias após a intervenção, sem dispersão nas bordas das áreas pulverizadas. Estes resultados apóiam as recomendações sobre o tempo-espaço, das medidas de proteção: na primeira metade da noite, no quintal, com animais de estimação criados pelo menos a cinco metros de distância dos seres humanos. A deltametrina como ela é usada, não parece muito eficaz neste cenário, nem o eventual uso de mosquiteiros pelo menos em adultos, devido ao lugar/hora de mais alta atividade de vôo da Lu. longipalpis. Este estudo acentua a necessidade de abordagem multidisciplinar, para desenvolver estratégias de prevenção baseadas tanto em estudos biológicos como antropológicos.

\section{ACKNOWLEDGMENTS}

We are grateful to the Secretaría de Calidad de Vida of the Municipalidad de Posadas for their technical support and assistance in the field; and the neighbors for their help. We want to thank the Sustainable Sciences Institute for the language revision. ODS is researcher of CONICET-Argentina, MSS and SAA have a scholarship from CONICET-Argentina.

\section{REFERENCES}

1. Alexander B, Maroli M. Control of phlebotomine sandflies. Med Vet Entomol. 2003;17:118.

2. Alexander B, Barros VC, de Souza SF, Barros SS, Teodoro LP, Soares ZR, et al. Susceptibility to chemical insecticides of two Brazilian populations of the visceral leishmaniasis vector Lutzomyia longipalpis (Diptera: Psychodidae). Trop Med Int Health. 2009; $14: 1272-7$.

3. Amóra SSA, Bevilaqua CML, Feijó FMC, Alves ND, Maciel MV. Control of Phlebotomine (Diptera: Psychodidae) leishmaniasis vectors. Neotrop Entomol. 2009;303:10

4. Andrade Filho JD, Galati EAB, Falcão AL. Redescription of Nyssomyia intermedia (Lutz \& Neiva, 1912) and Nyssomyia neivai (Pinto, 1926) (Diptera: Psychodidae). Mem Inst Oswaldo Cruz. 2003;98:1059-65.

5. Cabrera AL. Fitogeografia de La Republica Argentina. Bol Soc Argent Bot. 1971;14:1-42.

6. Correa Antonialli SA, Torres TG, Paranhos Filho AC, Tolezano JE. Spatial analysis of American visceral leishmaniasis in Mato Grosso do Sul State, Central Brazil. J Infect. 2007;54:509-14.

7. Courtenay O, Gillingwater K, Gomes PA, Garcez LM, Davies CR. Deltamethrin impregnated bednets reduce human landing rates of sandfly vector Lutzomyia longipalpis in Amazon households. Med Vet Entomol. 2007;21:168-76.

8. Courtenay O, Kovacic V, Gomes PA, Garcez LM, Quinnell RJ. A long-lasting topical deltamethrin treatment to protect dogs against visceral leishmaniasis. Med Vet Entomol. 2009;23:245-56.

9. David JR, Stamm LM, Bezerra HS, Souza RN, Killick-Kendrick R, Lima JW. Deltamethrin-impregnated dog collars have a potent anti-feeding and insecticidal effect on Lutzomyia longipalpis and Lutzomyia migonei. Mem Inst Oswaldo Cruz. 2001;96:839-47.
10. de Oliveira AG, Marassá AM, Consales CA, Dorval ME, Fernandes CE, de Oliveira GR, et al. Observations on the feeding habits of Lutzomyia longipalpis (Lutz \& Neiva, 1912) (Diptera: Psychodidae: Phlebotominae) in Campo Grande, an endemic area of visceral leishmaniasis in Mato Grosso do Sul, Brazil. Acta Trop. 2008;107:238-41.

11. de Oliveira AG, Andrade Filho JD, Falcão AL, Brazil RP. Estudo de flebotomíneos (Diptera, Psychodidae, Phlebotominae) na zona urbana da Cidade de Campo Grande, Mato Grosso do Sul, Brasil, 1999-2000. Cad Saúde Pública. 2003;19:933-44.

12. De Silans LN, Dedet JP, Arias JR. Field monitoring of cypermethrin residual effect on the mortality rates of the Phlebotomine sand fly Lutzomyia longipalpis in the state of Paraíba, Brazil. Mem Inst Oswaldo Cruz. 1998;93:339-44.

13. Falcão AL, Falcao AR, Pinto CT, Gontijo CMF, Falqueto A. Effect of deltamethrin spraying on the sandfly populations in a focus of American cutaneous leishmaniasis. Mem Inst Oswaldo Cruz. 1991;86:399-404.

14. Feliciangeli MD, Mazzarri MB, San Blas S, Zerpa O. Control trial of Lutzomyia longipalpis s.1. in the Island of Margarita, Venezuela. Trop Med Int Health. 2003;8:1131-6.

15. Feliciangeli MD, Arrivillaga JC, Bravo A, Arias F. Activity of Lutzomyia pseudolongipalpis and L. longipalpis s.1. (Diptera: Psychodidae) in Venezuela. Parasite. 2004;11:273-8.

16. Grimaldi G Jr, Tech RB, McMahon-Pratt D. A review of the geographic distribution and epidemiology of leishmaniasis in the New World. Am J Trop Med Hyg. 1989;41:687725 .

17. Gontijo CMF, Melo MN. Leishmaniose visceral no Brasil: quadro atual, desafios e perspectivas. Rev Bras Epidemiol. 2004;7:338-49.

18. Kelly DW, Mustafa Z, Dye C. Differential application of lambda-cyhalothrin control the sandfly Lutzomyia longipalpis. Med Vet Entomol. 1997;11:13-24.

19. Lainson R, Rangel EF. Lutzomyia longipalpis and the eco-epidemiology of American visceral leishmaniasis, with particular reference to Brazil: a review. Mem Inst Oswaldo Cruz. 2005;100:811-27.

20. Le Pont F, Padilla JM, Desjeux P, Richard A, Mouchet J. Impact de pulvérisations de deltraméthrine dans un foyer de leishmaniose de Bolivie. Ann Soc Belg Med Trop. 1989;69:223-32.

21. Maia-Elkhoury, Silveira AN, Waneska AA, de Sousa-Gomes ML, de Sen JM, Luna EA. Visceral leishmaniasis in Brazil: trends and challenges. Cad Saude Publica. 2008;24:2941-7.

22. Marcondes CB, Nascimento JA. Avaliação da eficiência de deltametrina (K-Othrine CE) no controle de Lutzomyia longipalpis (Diptera: Psychodidae), no Município de Santa Rita, Paraíba, Brasil. Rev Soc Bras Med Trop. 1993;26:15-8.

23. Missawa NA, Lorosa ES, Dias ES. Preferência alimentar de Lutzomyia longipalpis (Lutz \& Neiva, 1912) em área de transmissão de leishmaniose visceral em Mato Grosso. Rev Soc Bras Med Trop. 2008;41:365-8.

24. Monteiro EM, da Silva JC, da Costa RT, Costa DC, Barata RA, de Paula EV, et al Leishmaniose visceral: estudo de flebotomíneos e infecção canina em Montes Claros, Minas Gerais. Rev Soc Bras Med Trop. 2005;38:147-52.

25. Morrison AC, Ferro C, Pardo R, Torres M, Wilson ML, Tesh RB. Nocturnal activity patterns of Lutzomyia longipalpis (Diptera: Psychodidae) at an endemic focus of visceral leishmaniasis in Colombia. J Med Entomol. 1995;32:605-17.

26. Quinnell RJ, Dye C, Shaw JJ. Host preferences of the phlebotomine sandfly Lutzomyia longipalpis in Amazonian Brazil. Med Vet Entomol. 1992;6:195-200.

27. Quinnell RJ, Dye C. An experimental study of the peridomestic distribution of Lutzomyia longipalpis (Diptera: Psychodidae). Bull Entomol Res. 1994;84:379-82.

28. Quinnell RJ, Dye C. Correlates of the peridomestic abundance of Lutzomyia longipalpis (Diptera: Psychodidae) in Amazonian Brazil. Med Vet Entomol. 1994;8:219-24. 


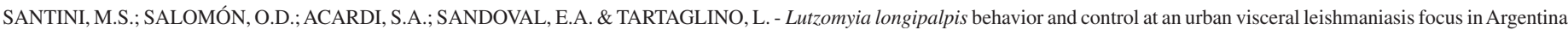
Rev. Inst. Med. Trop. Sao Paulo, 52(4): 187-91, 2010.

29. Rebêlo JM. Frequiência horária e sazonalidade de Lutzomyia longipalpis (Diptera: Psychodidae: Phlebotominae) na Ilha de São Luís, Maranhão, Brasil. Cad Saude Publica. 2001;17:221-7.

30. Salomón OD, Ramos LK, Quintana MG, Acardi SA, Santini MS, Schneider A. Distribución de vectores de leishmaniasis visceral en la provincia de Corrientes 2008 Medicina (B Aires). 2009;69:625-30

31. Salomón OD, Sinagra A, Nevot MC, Barberian G, Paulin P, Estevez JO, et al. First visceral leishmaniasis focus in Argentina. Mem Inst Oswaldo Cruz. 2008;10:109-11.

32. Salomón OD, Orellano PW. Lutzomyia longipalpis in Clorinda, Formosa province, an area of potential visceral leishmaniasis transmission in Argentina. Mem Inst Oswaldo Cruz. 2005;100:475-6.

33. Salomón OD, Sosa Estani S, Rossi GC, Spinelli GR. Presencia de Lutzomia longipalpis y la situación de la leishmaniasis visceral en la Argentina. Medicina (B Aires). 2001;61:174-8.
34. Sant'Anna MR, Jones NG, Hindley JA, Mendes-Sousa AF, Dillon RJ, Cavalcante RR, et al. Blood meal identification and parasite detection in laboratory-fed and fieldcaptured Lutzomyia longipalpis by PCR using FTA databasing paper. Acta Trop. 2008;107:230-7.

35. Sudia WD, Chamberlain RW. Battery operated light trap, an improved model. Mosquito News. 1962;22:126-9.

36. Teodoro U, Santos DR, Santos AR, Oliveira O, Poiani LP, Kühl JP, et al. Avaliação de medidas de controle de flebotomíneos no Norte do estado do Paraná, Brasil. Cad Saúde Pública. 2007;23:2597-604.

37. Zeledón R, Murillo J, Gutierrez H. Observaciones sobre la ecología de Lutzomyia longipalpis (Lutz \& Neiva, 1912) y posibilidades de existencia de leishmaniasis visceral en Costa Rica. Mem Inst Oswaldo Cruz. 1984;79:455-9.

Received: 6 January 2010

Accepted: 11 June 2010 